\title{
Skjelettaffeksjon ved sarkoidose
}

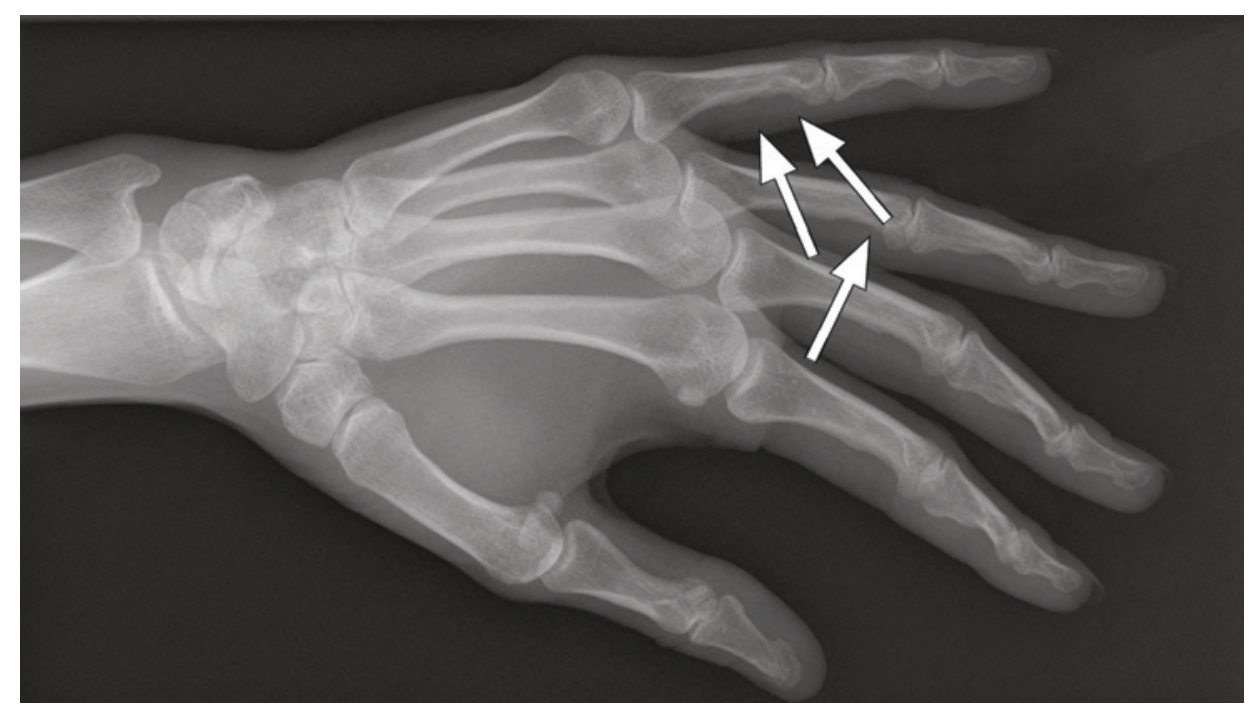

En kvinne i 40-årene fikk for ti år siden stilt diagnosen lungesarkoidose. Sykdommen debuterte som en variant av Löfgrens syndrom (akutt sarkoidose) med leddhevelser, erythema nodosum og forstørrede hilusglandler på røntgen thorax (1). Angiotensinkonverterende enzym var lett økt. I tillegg hadde hun anstrengelsesdyspné og patologisk spirometri.

Senere utviklet hun en rekke organmanifestasjoner, og mange differensialdiagnostiske muligheter ble diskutert. Biopsier fra magesekk og conjunctiva viste granulomatøs betennelse forenlig med sarkoidose.

Som ledd i utredning av langvarige smerter i hendene ble det tatt røntgenbilder. Bildene, tatt med skråopptak, viste kortikal utsparing i skjelettet i fjerde og femte grunnfalang (piler). Funn av slik skjelettaffeksjon støttet diagnosen sarkoidose.

Radiologisk skjelettaffeksjon forekommer hos $1-13 \%$ av sarkoidosepasientene (2). De vanligste røntgenologiske skjelettforandringene ved sarkoidose er lytiske lesjoner med bølgeform og gitterverksmønster. Skjelettforandringer ved sarkoidose forekommer vanligst $i$ hender, og patologiske frakturer kan forekomme (3).

Pasienten har gitt samtykke til at artikkelen blir publisert.

\section{Agnete Malm Gulati}

agnete.malm.gulati@stolav.no

Revmatologisk avdeling

\section{Annja T. Viset}

Klinikk for bildediagnostikk

\section{Mari Hoff}

Revmatologisk avdeling

St. Olavs hospital

Agnete Malm Gulati (f. 1981) er lege i spesialisering i revmatologi.

Forfatter har fylt ut ICMJE-skjemaet og oppgir ingen interessekonflikter.
Annja T. Viset (f. 1970) er overlege og spesialist i radiologi.

Forfatter har fylt ut ICMJE-skjemaet og oppgir ingen interessekonflikter.

Mari Hoff (f. 1968) er ph.d., overlege og spesialist i revmatologi.

Forfatter har fylt ut ICMJE-skjemaet og oppgir ingen interessekonflikter.

\section{Litteratur}

1. Löfgren S. Primary pulmonary sarcoidosis. I. Early signs and symptoms. Acta Med Scand 1953; 145: 424-31.

2. James DG, Neville E, Carstairs LS. Bone and joint sarcoidosis. Semin Arthritis Rheum 1976; 6: 53-81.

3. Moore SL, Teirstein AE. Musculoskeletal sarcoidosis: spectrum of appearances at MR imaging.

Radiographics 2003: 23: 1389-99.

Mottatt 29.1. 2013, første revisjon innsendt 15.3. 2013, godkjent 25.3. 2013. Medisinsk redaktør Merete Kile Holtermann. 